\title{
UWARUNKOWANIA FUNKCJONOWANIA KLASTRÓW W POLSCE W LATACH 2010-2014
}

Z a r y s t r e ś c i: Publikacja zawiera opis teoretyczny idei klastrów, uwarunkowania funkcjonowania klastrów w Polsce oraz inne aspekty dotyczące zagadnienia gron nie tylko w odniesieniu do RP. Podstawowym celem było przeprowadzenie analizy sytuacji klastrów w Polsce. Zakres czasowy obejmował lata 2010-2014. Badanie przeprowadzono na podstawie trzech raportów sporządzonych na zlecenie Polskiej Agencji Rozwoju Przedsiębiorczości: „Benchamrking Klastrów w Polsce - Raport z badania 2010”, „Benchmarking Klastrów w Polsce - edycja 2012. Raport z badania” oraz „Benhmarking Klastrów w Polsce - edycja 2014. Raport z badania”. Na końcu publikacji przedstawiono uzyskane wyniki.

S ł o w a k l u c z o w e: klastry; klastry w Polsce; benchmarking klastrów w Polsce

\section{WSTĘP}

W dobie stale rosnącej konkurencji przedsiębiorcy są zmuszeni do stosowania nowych innowacyjnych rozwiązań, stymulujących kreowanie konkurencyjności. Koncepcja klasteringu stanowi nowy rozdział dla przedsiębiorstw w odniesieniu do płaszczyzn regionalnych. Zmienia to sposób działania, prowadząc do współpracy uczestników danego klastra. Wychodząc naprzeciw zagrożeniom wynikającym z monopolizacji rynku, już w latach 90. powstała idea klasteringu skupiona na wielopłaszczyznowym rozwoju jednostek lokalnych oraz regionalnych.

* Adres do korespondencji: Alicja Majewska, Uniwersytet Szczeciński, Wydział Zarządzania i Ekonomiki Usług, ul. Cukrowa 8, 71-004 Szczecin, e-mail: amazonka. stawy@wp.pl 
Na zlecenie Ministerstwa Gospodarki w 2012 r. został przeprowadzony Foresight Technologiczny, mający na celu wyznaczenie strategicznych szlaków oraz kierunków rozwoju przemysłowego. Został zrealizowany w intencji wskazania przyszłych potrzeb oraz szans i zagrożeń, które związane są z rozwojem społecznym oraz gospodarczym. Według raportu polityka przemysłowa kraju powinna być nastawiona na działania wspierające jego długookresowy wzrost oraz rozwój przemysłu, nakierowujący na podnoszenie innowacyjności oraz postępu technologicznego w Polskich przedsiębiorstwach [Foresight technologiczny, 2012, s. 5-18]. Badania naukowe dotyczące relacji kooperacyjnych i jakości systemów regionalnych nie dają jasnych wniosków odnośnie do pozytywnego wpływu kooperacji na poziom aktywności innowacyjnej [Fritsch, Grit, 2004, s. 245-255]. Wielu autorów potwierdza hipotezę pozytywnego efektu klasteringu, wpływającego na podniesienie poziomu konkurencyjności oraz innowacyjności regionów w krajach wysokorozwiniętych, natomiast podaje w wątpliwości tę zależność w pozostałych regionach, takich jak Polska [Świadek, 2013, s. 463-474].

Głównym celem badawczym była analiza sytuacji klastrów w Polsce. Badanie zostało przeprowadzone na podstawie raportów: „Benchamrking Klastrów w Polsce - Raport z badania 2010”, „Benchmarking Klastrów w Polsce - edycja 2012. Raport z badania” oraz „Benhmarking Klastrów w Polsce - edycja 2014. Raport z badania”. Rozdział pierwszy zawiera teoretyczne definicje oraz aspekty klastrów w Polsce i na świecie. Wyszczególnione zostały instytucje zajmujące się omawianą problematyką. Drugi punkt rozprawy to analiza sytuacji klastrów w Polsce na podstawie trzech edycji badań benchmarkingów. Wnioski końcowe to konkluzje z dokonanej analizy - zaobserwowane zależności i obraz sytuacji klastrów na przestrzeni pięciu lat.

\section{ASPEKTY TEORETYCZNE KLASTRÓW}

Klasyczne pojęcie klastra, najczęściej cytowane w literaturze ekonomicznej, zostało opracowane przez M. Portera i zdefiniowane jako: ,geograficzne skupisko wzajemnie powiązanych firm, wyspecjalizowanych dostawców, jednostek świadczących usługi, firm działających w pokrewnych sektorach i związanych z nimi instytucji w poszczególnych dziedzinach, konkurujących między sobą, ale także współpracujących" [Porter, 2001, s. 16]. W następstwie czego powstało wiele podobnych 
definicji klastrów. OECD (Local Economic and Employment Development) określiło klastry jako „lokalne skupiska powiązanych horyzontalnie lub wertykalnie firm, działających w pokrewnych sektorach, wraz z innymi instytucjami wobec nich komplementarnymi" [http://www. oecd.org/czech/35136926.pdf]. Sama teoria klasteringu jest postrzegana wśród ekonomistów jako naturalny element rozwoju gospodarczego. Wynika to pośrednio z faktu, że inicjatywa klastrowa stała się popularna w trakcie tworzenia innowacyjnej polityki regionalnej, określającej miarę konkurencyjności oraz innowacyjności danego regionu, zależnej od sektorowej specjalizacji oraz współpracy przedsiębiorstw w danej sieci. Dość duże zainteresowanie tematem klasteringu wynika z powszechnego poglądu, że klastry są formą podmiotu o wysokim potencjale innowacyjnym, przez co odgrywają kluczową rolę w nakreślaniu poziomu konkurencyjności oraz rozwoju społeczno-gospodarczego [Hołub-Iwan, Machałowska, 2008, s. 9]. Motywacją do uczestnictwa w gronie może być chęć dostania się do interesujących zasobów, takich jak: wiedza, informacja, innowacje, dotacje [Gemra, 2014, s. 5]. Dodatkowo udział w klastrze może bezpośrednio przyczynić się do innowacji poprzez mobilizację do grupowego podejmowania ryzyka oraz rozłożenia kosztów i wspólną realizację wyznaczonych celów.

W Polsce od dawna istnieją instytucje, które zajmują się zagadnieniem klastrów. Są to między innymi: Centrum Analiz Społeczno-Ekonomicznych (CASE), Instytut Badań nad Gospodarką Rynkową (IBnGR), Ministerstwo Gospodarki i Pracy (MGiP), Ministerstwo Nauki i Szkolnictwa Wyższego (MNiSW), Polska Agencja Rozwoju Przedsiębiorczości (PARP) oraz wiele serwisów internetowych poświęconych tej tematyce. W 2013 r. w Sejmie odbył się Pierwszy Kongres Klastrów Polskich. Uczestnicy kongresu poruszali kwestie sytuacji oraz wspierania klasteringu w Polsce. Motyw klastrów jest tematem wielu publikacji i przeprowadzanych badań, co dowodzi operatywności przedsięwzięcia klasteringu. W krajach wysokorozwiniętych klastry odniosły sukces i poprawiły konkurencyjność kraju pośrednio poprzez postęp gospodarek lokalnych. Stąd zainteresowanie klastrami również w Polsce.

Prace badawcze nad zjawiskiem tzw. Terza Italia (zjawisko koncentracji firm w danych regionach i branżach) były realizowane w Polsce już w latach 70. Analizy dotyczące możliwości wystąpienia struktur klastrowych w RP zostały przeprowadzone na początku lat 90., natomiast pierwsze badanie klastrów w Polsce zostało przeprowadzone w 2002 r. przez Instytut Badań nad Gospodarką Rynkową [Benchmarking..., 201, s. 13]. 
Największe zainteresowanie odnoszące się do powiązań sieciowych zostało przejęte przez Polską Agencję Rozwoju Przedsiębiorczości. PARP wspiera klastry oraz inicjatywy klastrowe w różnorodny sposób. Na stronie internetowej agencji jest dostępnych wiele artykułów na temat klastrów. Począwszy od wskazówek, jak założyć klaster, po wyniki badań i analizy klasteringu w Polsce. Jednym z punktów, jakie realizuje PARP, jest raport z regularnego badania klastrów w Polsce - benchmarking klastrów w Polsce - przygotowany w ramach Europejskiego Funduszu Społecznego, przy udziale środków z Unii Europejskiej. Począwszy od 2010 r., odbywa się cyklicznie, co dwa lata. Do tej pory miały miejsce trzy benchmarkingi klastrów. Pierwszy w 2010 r., drugi w 2012 oraz ostatni w 2014 r. Dodatkowo na zlecenie PARP są sporządzane odrębne raporty ewaluacyjne dotyczące zmian klastrów w Polsce na przestrzeni konkretnego czasu, skupiające się na konkretnych problemach, np. ewaluacja klastrów wschodniej Polski ze szczególnym uwzględnieniu wsparcia dofinansowania PO RPW ${ }^{1}$. Polska Agencja Rozwoju Przedsiębiorczości kładzie nacisk na tworzenie się struktur klastrowych, ponieważ uważa, że są one motorem gospodarek krajowych, wzmacniają innowacyjność oraz konkurencyjność uczestników klastra, a co za tym idzie - również krajowej gospodarki. W Polsce nie ma innych raportów z funkcjonowania gron, które obejmowałyby taki zakres czasowy oraz obszar całego kraju. Istnieją publikacje analizujące dane grono i sytuację jego otoczenia, ale żadna nie jest sporządzana na tak dużą skalę.

\section{ANALIZA BENCHMARKINGÓW KLASTRÓW W POLSCE Z LAT 2010, 2012, 2014}

Benchmarking klastrów w Polsce analizuje funkcjonowanie gron na różnych płaszczyznach w dobranej grupie badawczej klastrów, gdzie głównym narzędziem były kwestionariusze. Dobór grupy badawczej w 2012 r. odbył się w pięciu krokach (w 2010 r. nie podano zasadności wybranych podmiotów). Pierwszym było wyłonienie klastrów w Polsce z dostępnych źródeł, głównie internetowych. Drugi krok to wyłonienie listy głównej oraz rezerwowej na podstawie danych kryteriów, gdzie atutem było uzyskanie zewnętrznego wsparcia finansowego w ostatnich latach oraz rozpoznawal-

1 Więcej: http://www.parp.gov.pl/files/74/75/77/20264.pdf, „Ewaluacja pt. Jak zmieniają się klastry dzięki wsparciu z PO RPW?” 
ność gron w mediach, strategiach innowacji na poziomie krajowym oraz regionalnym. W badaniu z roku 2014 wzięło udział tylko 20 gron uczestniczących w poprzednim benchmarkingu, zatem do badań zakwalifikowano 15 nowych podmiotów. W 2014 r. uczestniczyło 31 klastrów z poprzedniego badania.

Podstawowymi obszarami przeprowadzonych badań są: zasoby w klastrze, procesy w klastrach, wyniki klastra oraz potencjał wzrostu. Obszary badań zostały powiązane z 15 podobszarami. Cztery podobszary zmieniły się na przełomie lat 2010 i 2012. Pozostałe zostały rozpatrzone w podobny sposób. Zmienne oznaczają średnie benchmarkingu (skala 1-10) dla badanej grupy. W ostatniej edycji - 2014 - średnie dla podobszarów zostały zamieszczone w tabeli zbiorczej, przedostatnie - 2014 - obliczone z podziałem w zależności od modelu klastrów oraz liczby podmiotów w gronach. Rok 2010 ma obliczone uśrednione dane dla podobszarów, lecz niewpisane w tabelę. Analiza treści pozwoliła na naniesienie wartości. Wyliczenie średniej dla każdego podobszaru i umieszczenie wyników w tabeli pozwoliło na dokładniejsze przyjrzenie się zmianom, jakie nastąpiły na przełomie lat 2010-2014.

Tabela 1. Obszary działalności klastrów w Polsce w latach 2010-20114

\begin{tabular}{|c|c|c|c|c|c|}
\hline & & & 2010 & 2012 & 2014 \\
\hline \multirow{7}{*}{ 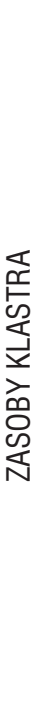 } & \multirow{4}{*}{$\begin{array}{l}\text { ZASOBY LUDZKIE } \\
\text { „KNOW-HOW" } \\
\text { KLASTRA }\end{array}$} & $\begin{array}{l}\text { Łączne zatrudnienie w podmiotach funkcjo- } \\
\text { nujących w rdzeniu klastra }\end{array}$ & 1,53 & 1,89 & 0,86 \\
\hline & & $\begin{array}{l}\text { Liczba osób prowadzacych klaster - obsłu- } \\
\text { ga administracyjna klastra }\end{array}$ & 1,38 & 2,76 & 2,63 \\
\hline & & $\begin{array}{l}\text { Liczba podmiotów uczestniczących w kla- } \\
\text { strze }\end{array}$ & 3,11 & 2,34 & 3,63 \\
\hline & & $\begin{array}{l}\text { Liczba zatrudnionych w działalności B+R } \\
\text { w rdzeniu klastra }\end{array}$ & 1,38 & 1,56 & 0,88 \\
\hline & \multirow[t]{3}{*}{$\begin{array}{l}\text { ZASOBY } \\
\text { FINANSOWE } \\
\text { KLASTRA }\end{array}$} & $\begin{array}{l}\text { Udział środków własnych pochodzacychch } \\
\text { z samofinansowania w całkowitym budżecie } \\
\text { klastra }\end{array}$ & 1,22 & 3,86 & 2,97 \\
\hline & & $\begin{array}{l}\text { Zewnętrzne środki finansowe pozyskane na } \\
\text { projekty klastrowe w okresie ostatnich } 2 \text { lat }\end{array}$ & 1,16 & 1,35 & 0,51 \\
\hline & & $\begin{array}{l}\text { Budżet klastra w przeliczeniu na członków } \\
\text { partycypujących w jego finansowaniu }\end{array}$ & 1,31 & 1,36 & 0,53 \\
\hline
\end{tabular}


Cd. tab. 1

\begin{tabular}{|c|c|c|c|c|c|}
\hline & & & 2010 & 2012 & 2014 \\
\hline \multirow{3}{*}{ 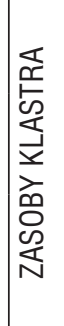 } & \multirow{3}{*}{$\begin{array}{l}\text { ZASOBY } \\
\text { INFRASTRUKTU- } \\
\text { RALNE }\end{array}$} & $\begin{array}{l}\text { Dostępność biur i sal konferencyjnych na } \\
\text { potrzeby klastra }\end{array}$ & 1,24 & 8,84 & 8,34 \\
\hline & & $\begin{array}{l}\text { Dostępność laboratoriów dla członków kla- } \\
\text { stra }\end{array}$ & 1,42 & 5,47 & 5,43 \\
\hline & & $\begin{array}{l}\text { Powszechność wykorzystania technologii } \\
\text { teleinformatycznych w wewnętrznej komu- } \\
\text { nikacji w klastrze }\end{array}$ & 1,71 & 6,51 & 4,2 \\
\hline \multirow{13}{*}{ 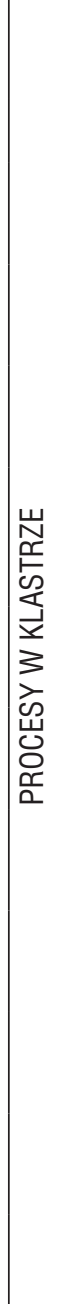 } & \multirow[t]{3}{*}{$\begin{array}{l}\text { AKTYWNOŚĆ } \\
\text { RYNKOWA }\end{array}$} & $\begin{array}{l}\text { Wspólne zaopatrzenie - wspólne zamówie- } \\
\text { nia }\end{array}$ & 1,71 & 2,06 & 1,54 \\
\hline & & Wspólne kanały dystrybucji & 1,87 & 3,66 & 2,03 \\
\hline & & $\begin{array}{l}\text { Wspólna oferta rynkowa przygotowana } \\
\text { przez klaster dla odbiorców z zewnątrz }\end{array}$ & 3,2 & 5 & 3,97 \\
\hline & \multirow[t]{3}{*}{ MARKETING I PR } & $\begin{array}{l}\text { Wspólne działania w zakresie promocji kla- } \\
\text { stra (ulotki, foldery, reklama w mediach) }\end{array}$ & 5,84 & 7,31 & 7,62 \\
\hline & & $\begin{array}{l}\text { Wspólna działalność targowo-wystawienni- } \\
\text { cza klastra }\end{array}$ & 4,16 & 5,89 & 4,31 \\
\hline & & $\begin{array}{l}\text { Wspólny system identyfikacji wizualnej kla- } \\
\text { stra (m.in.wspólne logo, kolorystyka, papier } \\
\text { firmowy) }\end{array}$ & 5,02 & 6,37 & 6,71 \\
\hline & \multirow[t]{4}{*}{$\begin{array}{l}\text { KOMUNIKACJA } \\
\text { W KLASTRZE }\end{array}$} & $\begin{array}{l}\text { Regularne spotkania podmiotów w klastrze } \\
\text { (w tym imprezy integracyjne) }\end{array}$ & bd & 7,34 & 7,43 \\
\hline & & $\begin{array}{l}\text { Różnorodność narzędzi, technik i form ko- } \\
\text { munikacji }\end{array}$ & bd & 7,17 & 6,34 \\
\hline & & $\begin{array}{l}\text { Efektywność i skuteczność wymiany infor- } \\
\text { macji i wiedzy }\end{array}$ & bd & 6,54 & 5 \\
\hline & & $\begin{array}{l}\text { Poziom nieformalnej wymiany wiedzy i in- } \\
\text { formacji między członkami klastra }\end{array}$ & bd & 7,43 & 7,8 \\
\hline & \multirow{3}{*}{$\begin{array}{l}\text { KREOWANIE } \\
\text { WIEDZY } \\
\text { I INNOWACJI }\end{array}$} & $\begin{array}{l}\text { Wspólne prace nad innowacyjnymi produk- } \\
\text { tami i technologiami }\end{array}$ & 3,47 & 5,89 & 5 \\
\hline & & $\begin{array}{l}\text { Wspólnie prace nad innowacjami organiza- } \\
\text { cyjnymi i marketingowymi }\end{array}$ & 3,02 & 4,94 & 3,4 \\
\hline & & $\begin{array}{l}\text { Wspólne szkolenia, warsztaty, konferencje } \\
\text { i wizyty studyjne (edukacja pracowników) }\end{array}$ & 5,11 & 6,69 & 5,63 \\
\hline
\end{tabular}


Cd. tab. 1

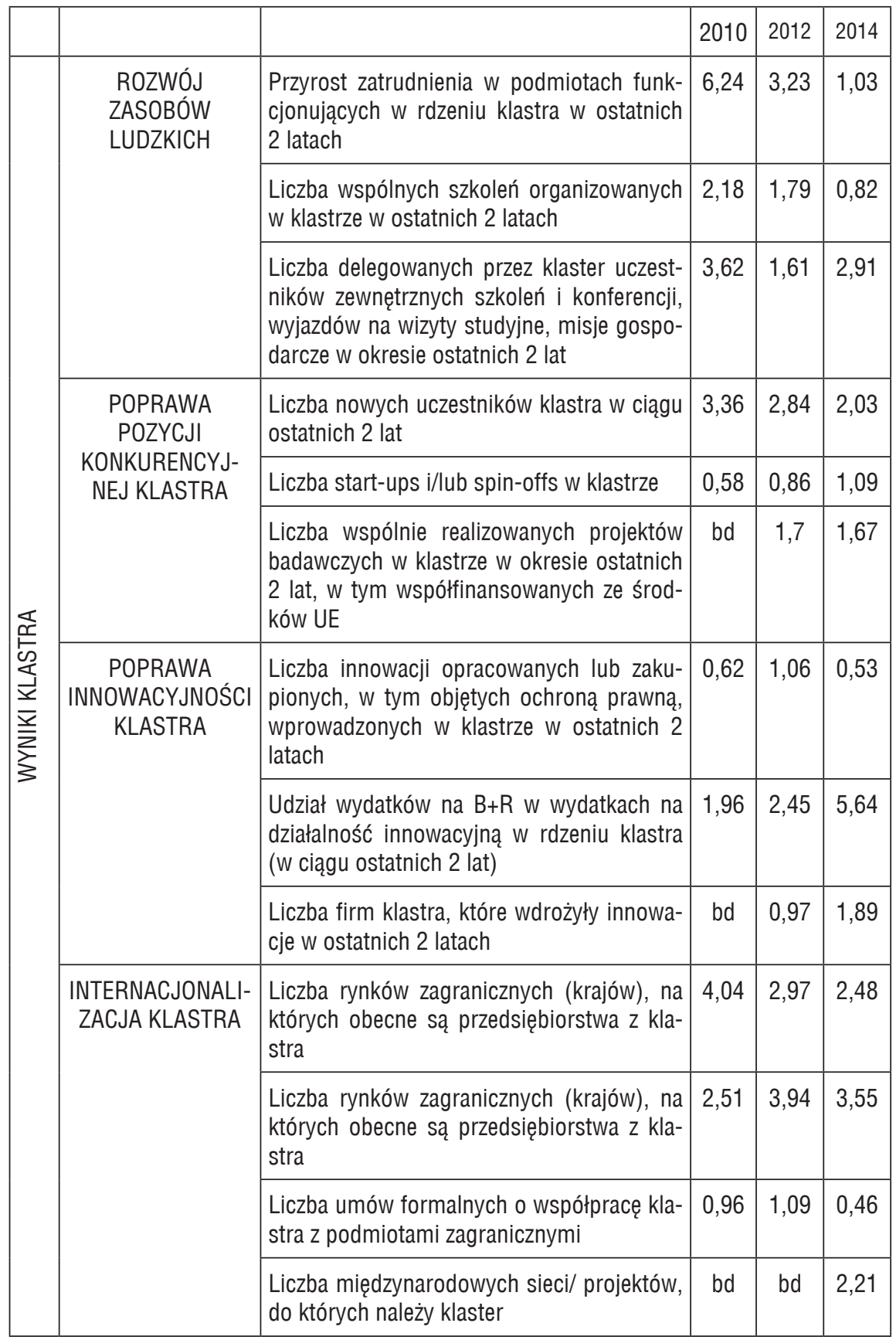


Cd. tab. 1

\begin{tabular}{|c|c|c|c|c|c|}
\hline & & & 2010 & 2012 & 2014 \\
\hline \multirow{14}{*}{ 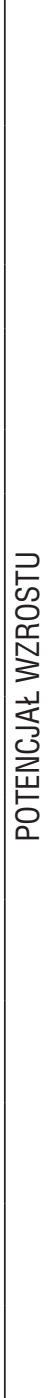 } & \multirow[t]{4}{*}{$\begin{array}{l}\text { UWARUNKOWA- } \\
\text { NIA REGIONALNE }\end{array}$} & $\begin{array}{l}\text { Potencjał, zasoby naturalne, tradycje go- } \\
\text { spodarcze lokalnego środowiska w rdzeniu } \\
\text { klastra w ostatnich } 2 \text { latach }\end{array}$ & 6,56 & 8,04 & 7,23 \\
\hline & & $\begin{array}{l}\text { Dostępność i mobilność pracowników wy- } \\
\text { soko wykwalifikowanych w ostatnich } 2 \text { la- } \\
\text { tach }\end{array}$ & 5,78 & 7,04 & 5,63 \\
\hline & & Atrakcyjność inwestycyjna regionu & 6,2 & 7,88 & 7,83 \\
\hline & & $\begin{array}{l}\text { Otwartość środowiska lokalnego/regional- } \\
\text { nego na współpracę }\end{array}$ & 5,51 & 6,45 & 7,23 \\
\hline & \multirow{4}{*}{$\begin{array}{c}\text { POLITYKA WŁADZ } \\
\text { PUBLICZNYCH } \\
\text { NA RZECZ } \\
\text { ROZWOJU } \\
\text { KLASTRA }\end{array}$} & Promocja klastra przez władze publiczne & 4,24 & 5,53 & 7,06 \\
\hline & & $\begin{array}{l}\text { Wspieranie finansowe rozwoju klastra przez } \\
\text { władze publiczne }\end{array}$ & 2,13 & 3,84 & 3,69 \\
\hline & & $\begin{array}{l}\text { Pomoc szkoleniowo-edukacyjna i organiza- } \\
\text { cyjna dla klastra }\end{array}$ & 2,64 & 3,92 & 3,11 \\
\hline & & $\begin{array}{l}\text { Dostosowywanie zmian w systemie edukacji } \\
\text { do potrzeb klastra }\end{array}$ & 4,4 & 5,45 & 6,29 \\
\hline & \multirow{3}{*}{$\begin{array}{l}\text { OTOCZENIE } \\
\text { INSTYTUCJONAL- } \\
\text { NE }\end{array}$} & $\begin{array}{l}\text { Dostosowanie usług szkoleniowo-dorad- } \\
\text { czych i informacyjnych do potrzeb klastra }\end{array}$ & 5,33 & 5,5 & 5,4 \\
\hline & & $\begin{array}{l}\text { Dostępność funduszy wspierających rozwój } \\
\text { klastra }\end{array}$ & 2,73 & 3 & 5,9 \\
\hline & & $\begin{array}{l}\text { Otwartość na współpracę i jakość sektora } \\
\text { nauki i } B+R \text { w regionie }\end{array}$ & $b d$ & 6,49 & 7,17 \\
\hline & \multirow[t]{3}{*}{$\begin{array}{l}\text { ZARZACDZANIE } \\
\text { KLASTREM }\end{array}$} & $\begin{array}{l}\text { Przywództwo w klastrze (siła i pozycja) ko- } \\
\text { ordynatora w klastrze }\end{array}$ & 7,31 & 8 & 7,4 \\
\hline & & $\begin{array}{l}\text { Aktywność koordynatora na rzecz animacji } \\
\text { współpracyw klastrze }\end{array}$ & 6,96 & 8,19 & 8,37 \\
\hline & & $\begin{array}{l}\text { Aktywność klastra względem otoczenia ze- } \\
\text { wnętrznego }\end{array}$ & 5,24 & 8,11 & 8,8 \\
\hline
\end{tabular}

Źródło: Benhmarking Klastrów w Polsce - edycja 2014. Raport z badania, opracowanie własne na podstawie: Benchamrking Klastrów w Polsce - Raport z badania 2010 , Benchmarking Klastrów w Polsce - edycja 2012. Raport z badania. 
Kolorem zielonym zostały oznaczone obszary, w których odnotowano wzrost, natomiast czerwonym kolorem zostały oznaczone komórki, gdzie nastąpił spadek względem wyników badań z poprzednich lat. Ponieważ badany obszar zawierał nieznaczne różnice $\mathrm{w}$ analizowanym zakresie, w niektórych komórkach nie uzyskano danych i oznaczono je skrótem bd (brak danych).

Pierwsza kolumna tabelki odnosząca się do danych z roku 2010 zawiera jedynie podane wyniki, jakie uzyskano podczas badania Benchmarking Klastrów w Polsce 2010, druga kolumna natomiast to wyniki wartości osiągniętych podczas drugiej edycji badania w $2012 \mathrm{r}$. Widoczna jest poprawa względem poprzedniego roku, szczególnie w obszarze procesy $w$ klastrze i potencjał wzrostu. Komunikacja w klastrze nie była badana wcześniej, więc nie odnotowano jej stosunku do zeszłego badania, natomiast pozostałe wyniki poprawiły się, w szczególności kreowanie wiedzy i innowacji, gdzie wartość średnia benchmarkingu wzrosła w większości punktów o 1-2 jednostki w jego dziesięciopunktowej skali. Warto zauważyć również, że w omawianym podobszarze firmy uzyskały wartości maksymalne 10 punktów. Potencjał wzrostu również odnotowuje zmianę na lepszą. Tutaj jednak wyniki znajdują się w przedziale $0,17-2,87$, gdzie mniejsza wartość to dostosowanie usług szkoleniowo-doradczych i informacyjnych do potrzeb klastra, natomiast większa obejmuje aktywność klastra względem otoczenia instytucjonalnego. Podobne zmiany nastąpiły w obszarze zasoby klastra, gdzie pogorszeniu uległ jedynie podobszar liczba podmiotów uczestniczacych $w$ klastrze, których średnia spadła w przeciągu dwóch lat o 0,77. W obszarze wyniki klastra sytuacja uległa pogorszeniu, wnioskując po spadku średnich wartości równo połowy podobszarów. Odnotowano w nim największe zniżenie poziomów wartości, w dwóch przypadkach nawet o połowę w stosunku do poprzedniej ilości. Nie jest to dobra informacja, zwłaszcza jeśli było to zmniejszenie zatrudnienia w klastrze, lecz mogło wynikać z faktu, że zmniejszyła się średnia liczba podmiotów w badanych gronach.

Ostatnie badanie z roku 2014 przyniosło nowe fakty w kwestii funkcjonowania klastrów w Polsce. Wydłużenie się okresu obserwacji i analiz gron pozwoliło na delikatne wyznaczenie kierunku zmian, jakie nastąpiły w ciągu czterech lat prowadzonych rozważań. Nastąpiło załamanie wyników z przeprowadzanych badań wśród klastrów. Uległy one pogorszeniu, choć w większości przypadków nie do poziomu, jakie osiągały w 2010 r. Klastry, które brały udział w badaniu w pierwszej edycji benchmarkingu, znajdowały się w większości w fazie embrionalnej, natomiast w kolejnych 
benchmarkingach grona były w fazie wzrostu, zatem wyniki, jakie osiągnęły podczas analizy, są nieproporcjonalne do osiągniętej fazy rozwoju klastrów [A practical..., 2004, s. 11] i zaprzeczają teorii, która mówi o tym, że faza wzrostu przynosi największe korzyści dla gron, które się obecnie w niej znajdują, względem pozostałych okresów ich życia. Faza wzrostu to okres, w którym w klastrach wzrostowych (ang. established clusters) funkcjonuje już duża liczba podmiotów i ich koligacje z otoczeniem są silne. W ramach gron powstają nowe podmioty, tzw. spin off, a podmioty działające w gronie łączą się i ulegają przekształceniom. Polepszenie lokalnej pozycji konkurencyjnej pozwala na kontynuację podjętych procesów innowacyjnych [Kładź-Postolska, 2013, s. 95].

Wyniki analizy z roku 2014 ukazują, że Zasoby ludzkie „know how” klastra mają tendencję spadkową. Jedyny wzrost został zaobserwowany w zakresie liczby podmiotów w klastrze i po znaczącym spadku w 2012 r., przekroczył próg początkowy, jaki osiągnął w pierwszym badaniu w 2010 r. Jest to niewielka zwyżka, ale może przynieść prognozy na polepszenie się tego wyniku w przyszłych latach. Niepokojący jest fakt, że odnotowano znaczny spadek zatrudnionych w działalności $\mathrm{B}+\mathrm{R}$, która jest fundamentalną kwestią działalności klastrowej. Jej wartość spadła w sumie o 0,5 i aktualnie wynosi 0,88. Jednak udział wydatków na działalność $\mathrm{B}+\mathrm{R}$ w wydatkach na działalność innowacyjną wzrasta dość mocno. Obszar zasoby klastra w 9 na 10 podobszarów odnotowuje spadek wartości względem roku 2012, ale w stosunku do roku 2010 w 5 na 10 podobszarów. Cztery obszary pomimo ostatniego spadku nadal utrzymują miarę większą niż w pomiarach w pierwszym badaniu. W obszarze procesy w klastrze 9 na 13 podobszarów ma tendencję spadkową względem badania z roku 2012, a w porównaniu do 2010 r. tylko jeden podobszar: wspólne zaopatrzenie, pozostaje nadal na pozycji ujemnej. Pozostałe bardzo nieznacznie rosną. W czterech nie ma danych do przeanalizowania wyników pierwszego badania z ostatnim. Na wysokim poziomie lokuje się marketing i PR w gronach. Bardzo niski poziom uzyskał obszar wyniki klastra. Podobnie jak w Procesach w Klastrach, 9 na 13 podobszarów odnotowuje spadek. Najniższy sytuuje się na poziomie $0,46 \mathrm{w}$ dziedzinie liczby umów formalnych dotyczących współpracy z podmiotami zagranicznymi. Udział eksportu w strukturze sprzedaży produktów w rdzeniu klastra ma maksymalną wartość w tym obszarze, która wynosi 3,55 po spadku, jaki miała w 2012 r. z wartości 3,94. Jest to najwyższy wynik oraz największy przyrost jednostki z dziedziny Wyników. 
Ostatnią analizowaną płaszczyzną jest Potencjał Wzrostu, który niewątpliwie wypadł najlepiej. Jedynie 6 na 14 obszarów odnotowuje obniżenie się wartości benchmarkingi, z których tylko jedna pozostaje niższa względem pierwszego badania, jakie przeprowadzono w $2010 \mathrm{r}$. Jest to podobszar dostępność i mobilność pracowników wysoko wykwalifikowanych. Największą średnią dla badanych klastrów przypisuje się w podobszarze zarządzanie klastrem, gdzie nie odnotowano spadków na przełomie badanych lat i wyniki benchmarkingu osiągają wartości ponad 7 do prawie 9 w 2014 r. Można wywnioskować, że są to bardzo wysokie noty, biorąc oczywiście pod uwagę fakt, że liczby są uśrednione dla całej grupy badawczej, na której przeprowadzony został benchmarking. Największy przyrost nastąpił w podobszarze dostępność funduszy wspierających klaster i wyniósł 3,17 w okresie 4 lat.

\section{WNIOSKI KOŃCOWE}

Polska Agencja Rozwoju Przedsiębiorczości badała stan klastrów w Polsce w latach 2010-2014. Wyniki zostały umieszczone w trzech raportach. Służą jako baza wiedzy na temat sytuacji polskich gron. Naukowcy wielokrotnie powołują się na wymienione raporty, traktując je jako konstytutywne źródło ujmujące zmiany, jakie zaszły w Polsce na przełomie badanego okresu. Dokładna analiza trzech raportów: „Benchamarking Klastrów w Polsce - Raport z badania 2010”, „Benchmarking Klastrów w Polsce - edycja 2012. Raport z badania” oraz „Benhmarking Klastrów w Polsce - edycja 2014. Raport z badania”, pozwala wysnuć wiele interesujących wniosków na temat sytuacji klastrów w Polsce, ale generuje również wątpliwości. Już na samym początku bilansu benchmarkingów można dostrzec rozbieżności w doborze grupy badawczej. Obserwacje zostały przeprowadzone na dość małej grupie badawczej, o wątpliwej reprezentatywności. Dobór grupy został opisany wyłącznie w drugiej edycji badania, gdzie wskazano na wybór klastrów, które brały udział w poprzednim badaniu, co jest logiczne, ale pozostałe klastry to te, które uzyskały zewnętrzne wsparcie finansowe w ostatnich latach oraz są rozpoznawane $\mathrm{w}$ mediach, strategiach innowacji na poziomie krajowym i regionalnym [Benchmarking..., 2012, s. 19]. Tego typu selekcja świadczy o wyłonieniu (spośród zidentyfikowanych 250 klastrów w Polsce) gron prosperujących na najwyższym poziomie w skali kraju. Wobec takich faktów można wysnuć wnioski, że wyniki badań przedstawiają naj- 
lepszą z możliwych wersję, obrazującą aktualny stan rozwoju polskich klastrów.

Z raportów wynika, że uwarunkowania funkcjonowania klastrów w Polsce nie rokują zbyt dobrze przy założeniu, że badana grupa jest najlepsza spośród potencjalnie funkcjonujących w kraju.

Wyniki najbardziej aktualne (2014 r.) przedstawiają, że najwyższą wartość uzyskał obszar „Potencjał wzrostu”, w którym wartość benchmarkingu osiągnęła maksymalny poziom. Wyróżniającym się podobszarem jest „Zarządzanie klastrem", osiągający wysoki poziom wyników. W treści benchmarkingu - edycja 2014 autorzy zwracają uwagę na problem przywództwa, twierdząc, że wystąpiła bardzo duża rozbieżność pomiędzy wartościami uzyskanymi przez grona. Również wspieranie inicjatyw przez władze publiczne ma biegunowy charakter. W zależności od położenia i regionu klastry kooperujące z władzami publicznymi osiągają wsparcie finansowe lub nie nawiązują bliższej współpracy, co z kolei jest przyczyną najprawdopodobniej niedocenienia możliwości uzyskania korzyści z powiązań.

Analizując dalej uzyskane wielkości, najsłabiej wypada obszar „Rozwój zasobów ludzkich", który poprzez współpracę podmiotów w klastrach powinien intensywnie nabierać korzyści i wagi w funkcjonowaniu poszczególnych jednostek. Radykalnie zmalała liczba osób zatrudnionych w rdzeniu klastra według sposobów obliczania benchmarku. W dalszej części okazuje się, że poziom jest niski ze względu na nieproporcjonalność obliczeń. W tym konkretnym przypadku oznacza to, że w jednym z gron poziom ten znacznie się obniżył, natomiast wyniki pozostałych grup nie zostały ujęte, gdyż były one zbyt niskie w stosunku do grona wiodącego w tej kategorii. $\mathrm{Z}$ tego wynika, że wartości podane w tabeli nie odzwierciedlają rzeczywistego stanu rzeczy. Podobszar „Liczba wspólnych szkoleń” również przedstawia bardzo duży spadek względem poprzednich lat. Sytuacja jest jeszcze gorsza, ponieważ średnia liczba szkoleń w latach 2012-2014 wynosi 16\% dla badanej grupy, lecz jest ona sporo zawyżona przez jedno grono, które w ciągu dwóch lat zorganizowało 150 szkoleń. Te dwie sytuacje obrazują fakt, że badaną grupę należałoby rozpatrzyć indywidualnie, nie poprzez uśrednianie wyników, ponieważ uzyskane wartości nie obrazują sytuacji rzeczywistej ze względu na ich sporą polaryzację.

W interpretacji zagadnienia konkurencyjności klastrów, podmiotów do nich przynależnych, a poprzez to i gospodarki regionu czy kraju, również jednostkowo należałoby zbadać kwestię poprawy innowacyjności. Analizując wyniki zbiorcze, uśrednione dla badanych grup z zakresu innowacyjności gron na podstawie trzech benchmarkingów, można dostrzec delikatne 
zmiany wychodzące na niekorzyść klastrów. Liczba innowacji w roku 2012 znacznie wzrosła, natomiast w kolejnej edycji badania odnotowano spadek do wartości mniejszej niż pierwotna w badaniu z roku 2010, co jest bardzo niepokojącym sygnałem. Podobszar udział wydatków na sferę $\mathrm{B}+\mathrm{R}$ potroił swoją wartość w ostatniej edycji benchmarkingu, co z kolei może pozytywnie wpłynąć w kolejnych latach na poprawę innowacyjności klastrów w Polsce. Wzrasta również liczba firm, które wdrożyły innowacje w ciągu ostatnich dwóch lat, jednak prognozowanie w tak krótkim okresie może nie odzwierciedlić przyszłej sytuacji, zwłaszcza że innowacyjność to proces długofalowy. Same wartości benchamarkingu pozostają bardzo niskie w tym obszarze.

\section{LITERATURA}

Kładź-Postolska K., (2013), Współpraca $w$ klastrach $w$ różnych fazach ich cyklu życia, Gospodarka Narodowa, 11-12.

Hołub-Iwan J., Machałowska M., (2008), Rozwój klastrów w Polsce. Raport z badań, Szczecin.

Gemra S., (2014), Zarzadzanie klastrami w przedsiębiorstwach komunikacji samochodowej w Polsce - studium przypadku, Przegląd Organizacji 12/2014.

Fritsch M., Grit F., (2004), Innovation, regional knowledge spillovers and $R \& D$ cooperation, Research policy 33.2.

Świadek A., (2013), Lokalizacja konkurenta a aktywność innowacyjna peryferyjnych systemów przemysłowych $w$ Polsce, Ekonomia i Prawo 12.3.

Porter M.E., (2001), Porter o konkurencji, PWE, Warszawa.

A Practical Guide to Cluster Development, (2004), A Report to the Department of Trade and Industry and the English RDAs by Ecotec Research \& Consulting, London.

PARP: Benchmarking klastrów w Polsce - 2010. Raport ogólny,

Warszawa 2010.

PARP: Benchmarking klastrów w Polsce - edycja 2012. Raport ogólny, Warszawa 2012.

PARP: Benchmarking klastrów w Polsce - edycja 2014. Raport ogólny, Warszawa 2014.

http://www.oecd.org/czech/35136926.pdf [04.03.2015]

http://www.parp.gov.pl/files/74/75/77/20264.pdf [04.05.2015]. 


\title{
DETERMINANTS OF CLUSTERS IN POLAND IN 2010-2014
}

\begin{abstract}
A b stract: The publication contains a description of the theoretical idea of clusters, conditions of clusters in Poland and many other aspects of the issue grapes not only for Poland. The main objective was to analyze the situation of clusters in Poland. The time range included the years: 2010-2014. The study was conducted on the basis of three reports prepared for the Polish Agency for Enterprise Development: Benchamrking Clusters in Poland - Research Report 2010 Benchmarking Clusters in Poland - the 2012 edition report of the examination and Benhmarking Clusters in Poland - edition 2014 report from the study. At the end of this publication shows the results obtained.
\end{abstract}

K e y w or d s: Clusters; clusters in Poland; benchmarking of clusters in Poland, 